\title{
WHY SHOULD MENTORING STILL BE AN ISSUE ON THE FUTURE LABOUR MARKET?
}

\author{
Gabriella Horváth-Csikós
}

master teacher

\author{
Faculty of Economics and Social Sciences, Szent István University \\ E-mail: Horvath.Csikos.Gabriella@gtk.szie.hu
}

\begin{abstract}
The participants of the future labour market are the present-day secondary school and university students. The question of knowledge-management has become a highlighted issue nowadays in the companies' everyday life. Sharing of knowledge is necessary in the management practice of any competitive companies. Knowledge management has several forms and mentoring is one of them. The question may arise whether future jobs will require mentoring or automation will also solve this issue.
\end{abstract}

Kulcsszavak: labour market, knowledge management, automation, mentoring, human capital JEL besorolás: $\mathrm{I} 29$

LCC: H1-99

\section{Introduction}

The question of knowledge management/knowledge sharing has become more and more popular for the companies and organizations nowadays. Knowledge is the most important capital of the organizations, therefore developing and preserving it involves challenges and requirements for the institutions. The practice and concept of knowledge management has become a strategic field for several companies.

More and more Hungarian companies are realizing the advantages of the mentoring practice, which supports the professional and personal development of the employees. Several companies apply the mentoring system in order to help the entrants and in some cases provide them with linguistic support.

Although the mentoring system itself is not new, it has started to spread rapidly as international companies are mushrooming in Hungary. The mentoring practice has become an important part of the system of career development.

Due to the increasing speed of technological development and globalization, the speed of changes in job destruction and job creation also increases. According to some calculations, half of the present jobs will be ceased due to automation. Some studies suggest that approximately $65 \%$ of children entering primary school today will have jobs that do not yet exist. But will these jobs require the practice of mentoring? What are the expected future jobs? Can a new form of mentoring be developed? Is it necessary to develop a new form of mentoring at all?

The aim of this paper is to present a few of the future jobs which are expected to appear in the near future and see whether mentoring, as one form of knowledge sharing can be upgraded to meet the requirements of the needs of the future labour market. This paper is a 
theoretical overview; a practical research should later be carried out while considering the issue.

\section{Literature review}

The concept of 'knowledge management' means corporate policy, practice and tools, which make it possible for the individuals to understand how their jobs contribute to the entire the company, what benefits they might have and how they can contribute to the more efficient and more successful operation of their companies. The most important value and product of a given company is knowledge itself. The employees have to be encouraged to acquire, keep and transfer knowledge. (Nemirovsky and Solomon, 2000). The employees have to learn and apply different techniques in order to be able to convert their know-how systematically into an important knowledge-source for the organisation. (Choo, 1996).

The leaders have to support the establishment of a corporate culture where knowledge is value, knowledge-transfer is supported and innovation and development are considered important.

Effective knowledge-management requires new roles and responsibility from the leaders and the employees, as well. It is necessary that the participants of the process observe their own work from multiple perspectives, they can put forward their opinions, they are able to make and receive critical remarks and they have to be suitable and willing to share their knowledge with each other. Its success depends on several factors such as trust, cultural indifference, and lack of reception, communicational problems and the attitudes of the participants, among others. (Bencsik, 2009).

A study carried out in 2014 (Bencsik-Juhász-Kovács, 2014) examining the openness of the respondents with regard to their knowledge-sharing showed that the knowledge-sharing willingness of the respondents was basically average and they did not really welcome the idea to share their practical knowledge with the others. The respondents were less interest-centred and expectation-oriented with their friends, acquaintances and strangers in return of their knowledge-sharing than with the acquaintances of formal relationships. (Bencsik-JuhászKovács, 2014).

\section{Types of mentoring}

Byrne (1991) grouped mentoring in three simple but very clear categories. The three types are traditional mentoring, professional mentoring and formal mentoring.

\section{Traditional mentoring}

Traditional mentoring is the oldest form of mentoring and it has been applied by several patrons of arts and sciences throughout history. In the traditional sense, mentors are people who use their knowledge, power and status to assist their mentored and their careers.

\section{Professional mentoring}

Unlike traditional mentoring, professional mentoring is not established on the personal choice of the individual mentor; on the contrary, it is established by the proposal of the leader. One of the most important advantages of professional mentoring is that it is not compulsory but voluntary; thus success is not guaranteed. 


\section{Formal mentoring}

Formal and institutionalized mentoring makes mentoring a standard part of management practice. Therefore it can become a compulsory and core part of it. In organisations with formal mentoring, a small group of elderly staff and younger staff work together. The formal programmes are guided and supervised by the organisation. The advantage of formal mentoring is that anybody can participate in this programme.

Mentoring can provide the following key benefits to the mentored:

$\circ$ gets a clear view about his own career and personal goals

- helps him to get a better understanding of the organisation's culture and unspoken rules

$\circ$ he is exposed to new ideas and ways of thinking

○ provides networking contact for the mentored

$\circ$ gets access to new resources

$\circ$ gets the opportunity to develop new skills and knowledge

- will more likely be successful in his career

o increases his self-confidence

O teaches him how to speak up and be heard

$\circ$ his skills will develop in the field of interpersonal relationships

- learns how to manage feedback

During the process the mentor has the possibility to develop his management abilities and lift them to a higher level by:

o seeing the business from a leader's point of view

$\circ$ facing challenges, as he has to apply his knowledge in real situation

$\circ$ getting to know the new members of the organisation

o reminding him how to listen actively rather than passively

$\circ$ helping re-energize his career

$\circ$ he is exposed to fresh perspectives and ideas

$\circ$ it encourages him to share knowledge, which will increase his sense of self appreciation

O strengthens his interpersonal skills

- leads to a more personal satisfaction on his behalf

In addition to the fact that the process is beneficial for both parties, the organisation can enjoy several advantages, as well. Mentoring contributes to the continuous transfer of talent/knowledge and it provides the opportunity for the leaders of today to transfer their knowledge to the future leaders, which might result in the following:

$\circ$ employees will get a more self-confident knowledge about business life and the organisation

o retention of staff

- a more effective, more successful organisation

- a more developed communication within the organisation

$\circ$ it shows the outside world that the organisation values its employees

○ results is a more positive work environment

○ fosters leadership skills in mentors

- supports a sense of cooperation and harmony within the organisation

o increases the loyalty of employees towards the organisation -which can save money on recruitment and training costs

Figure 1 shows the life cycle of mentoring. 


\section{THE MENTORING LIFE CYCLE}

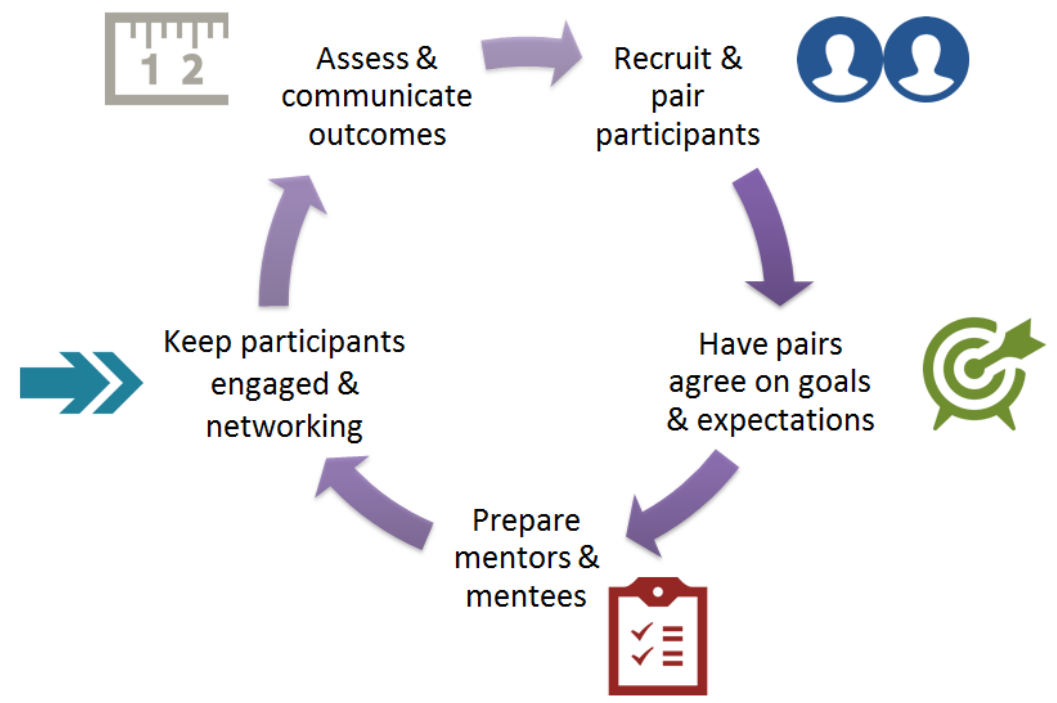

Figure 1: The mentoring life cycle

Source: https://www.apqc.org

Unfortunately, it is still typical in Hungary that employers expect the entrants when entering the company to possess the knowledge and skills the company requires. If the entrants cannot gain enough experience, then later this can be an obstacle for them to find a job. But who knows the requirements of the future jobs now? Who will be able to help the job-seekers and the entrants, as well to guide and support on their path on the labour market? At present it would be practical and useful that the present-day mentors support the would-be employees about the job opportunities and the possible requirements of future job market. Mentoring is often the missing link, which connects new employees with their future workplace successes (Levinson and McKee, 1978). If the previous one does not exist, the latter one should also be missing. Hungarian companies should think about their own future and they should invest money and energy into developing a new mentoring programme of their own while especially focusing on the requirements of the future jobs.

\section{Future jobs}

As technology changes, some old jobs will be ceased and some new ones will be created. If we believe what the estimates say about the percentage of job destruction due to automation, then who has to worry about losing his job? Are university students safe from this aspect? Will they find a position on the labour market connected to what they are studying at present? Do we have to worry about or do we have to be more prepared for what some studies say, namely, that $65 \%$ of the children entering primary school today will have jobs that do not exist yet?

What about teachers? Will we need fewer teachers in the future? If we want to achieve the sustainable development goals (SDGs) in education -which is to ensure inclusive and quality education for all and promote lifelong learning-, we would certainly need a lot more teachers than we have today. Training teachers should be the utmost priority of education. If we want to raise kids so that they could become independent, responsible adults with individual thoughts and who are creative thinkers and responsible decision makers, then definitely we have to put more emphasis on how to train the teachers of the future because it is the teachers who will teach our kids how to think individually, how to learn, how to bear responsibility and also how to maintain their curiosity. If these teachers or would-be teachers do not meet the previous 
criteria, if they are not individual and creative thinkers, they cannot pass it on how to be individual and creative. They have to receive the best of education.

As technology changes rapidly, it alters the way how we communicate and interact. Most of us communicate via the Internet; we spend a lot time in front of our computers and other technical gadgets. Teachers can also share their knowledge with students with the help of different devices and students can also share their own thoughts with their mentors or friends no matter where they are geographically. We can see that technology has become a language itself and children from an early age master this new language. They are already born with the know-how of operating these devices. Therefore, it is obvious that we all have to speak this new language if we want to remain part of the groups we are in. Using the Internet and tablets, i-pads and learning from TED-talks and podcasts will not dismiss teachers from all sectors, but for sure it will change the role of the teacher and it will broaden the learning experience.

The following tables show the least safe and the safest jobs according to the research of The Future of Employment.

Table 1: The least safe jobs

\begin{tabular}{|l|l|}
\hline Job & Chance of automation \\
\hline Telemarketer & $99 \%$ \\
\hline Loan officer & $98 \%$ \\
\hline Legal assistant & $94 \%$ \\
\hline Taxi driver & $89 \%$ \\
\hline Fast food cook & $81 \%$ \\
\hline
\end{tabular}

Source: The Future of Employment

Table 2: The safest jobs

\begin{tabular}{|l|l|}
\hline Job & Chance of automation \\
\hline $\begin{array}{l}\text { Mental health and substance abuse social } \\
\text { worker }\end{array}$ & $0.3 \%$ \\
\hline Occupational therapist & $0.35 \%$ \\
\hline Dietitian and nutritionist & $0.39 \%$ \\
\hline Physician and surgeon & $0.42 \%$ \\
\hline Clergy & $0.81 \%$ \\
\hline
\end{tabular}

Source: The Future of Employment

According to the report of the World Economic Forum (year of publication), 7 million jobs will disappear due to automation but 2 million new ones will be created. We can take it for granted that robots will take some of our jobs but they will create some new ones. The following jobs are positions on the future labour market, which do not exist yet; rather, they are the future jobs for the university students at present.

- Drone manager: After 10 -20 years, drones will not be considered new. Drone managers will control, maintain the fleet of drones at a given company.

- Private industry air traffic control: As drones will be a significant part of our everyday lives, we can take it for granted that different companies and organisations will have their own air traffic control system, which can be within the country or outside the country. 
- Medical mentor: Just like health coach or patient advocate, the position of a medical mentor is a possible option. There is a growing demand for a better and higher quality medical support and medical system.

- Wholeness mentor: Within the framework of "mindfulness" (being in the presence), the wholeness mentor will help us develop lifelong strategies, which might give us the harmony between job and private life including the hobbies we have in order to reach happiness in life.

- End-of-life coach: According to some studies, the majority of baby-boomers are really interested in how they will live their so-called end of life. This generation will approach the end of their lives within 10-20 years. The end-of-life coach will help them to make good decisions on how to spend their last years and they will support their mentored in finding the best medical treatments if necessary. In the forthcoming few years, there will be a massive shift toward people wanting to add more life to their days instead of adding more days to their life.

- Self-driving car mechanic: Self-driven cars will cease several positions but will create some new ones, as well.

- Autonomous transportation specialist: With drones and self-driven cars around us, it will be necessary to monitor the new traffic system and also to integrate, check and develop the new types of cars in the existing system.

- 3D Food Printer Chef

- 3D Printed Clothing Fashion Designers, Material Specialists, and Stylists

- Organ Harvester: There are currently several labs around the world that can grow human organs in a simple petri dish. Eventually technology will become commercially available and there will be a need for an organ harvester to plant and then harvest the organs prior to them being implanted by robot-surgeons.

- Organ Agents - 3D printed organs are being created. Scientists in Worcester Polytechnic Institute have found a way to use spinach to build working human heart muscle potentially solving a long-standing problem in efforts to repair damaged organs. ${ }^{8}$

- Future Agriculture: drones, swarmbots (multirobot systems)

- Plant-Jackers and Tree-Jackers - Plant and tree alteration specialists, who manipulate growth patterns, colour-changing leaves, personalized fruit, etc.

- Molecular Gastronomists

- Bio-Meat Factory Engineers

- Urban Agriculturalists - Why transport food from far when it can be grown next door?

- Plant Educators - An intelligent plant will be capable of re-engineering itself to meet the demands of tomorrow's marketplace

- Plant Psychologists \& Plant Therapists

Having seen the list of future jobs, we can agree that the role of almost all participants on the labour market will be different in the near future. They need to realize that with the radical change in technology, they need to adapt their behaviour, their way of understanding and attitude towards jobs and job requirements to the new circumstances. Using technology as the new-born language will be a basic requirement for all of them. And mentoring as such has to have an important role in helping and supporting the employees and employers to be able to adapt to the new situations.

\footnotetext{
${ }^{8}$ https://news.nationalgeographic.com/2017/03/human-heart-spinach-leaf-medicine-science/
} 
We know that new forms of mentoring have appeared in the last ten years. One form is when it is not the senior, experienced managers who teach, but on the contrary, the junior employees act as mentors in order to teach their elder colleagues something new, especially when they teach them new technologies (Harvey, McIntyre, Heames \& Moeller, 2009). The so-called reversed or reciprocal mentoring came to life basically because of globalization, quick technological development and market requirements. Harvey et al. (2009) summarized that students graduating from colleges and universities have high level knowledge of the Internet, computer studies and other web-based technologies and they are very enthusiastic to share their knowledge with the others. This form of mentoring has positive effects on both participants.

David Clutterbuck (2002) introduced the concept of structured developing mentoring in Europe. According to Clutterbuck we talk about mentoring when somebody uses his own wisdom to build the other's wisdom. This shows and expects a really high level of intellectual and emotional intelligence from the members of the relationship. Is a new type of structured reciprocal mentoring about to develop in the near future to help the participants of the labour market to get used to the new job requirements? With this article my aim was to generate a thought-provoking thinking from all the participants of any mentoring and knowledge management processes.

We could see that mentoring has undergone a certain paradigm shift recently; more youngsters are present in the mentoring processes as mentors. And yes, something interesting is happening. Some things have already been reversed and reciprocal.

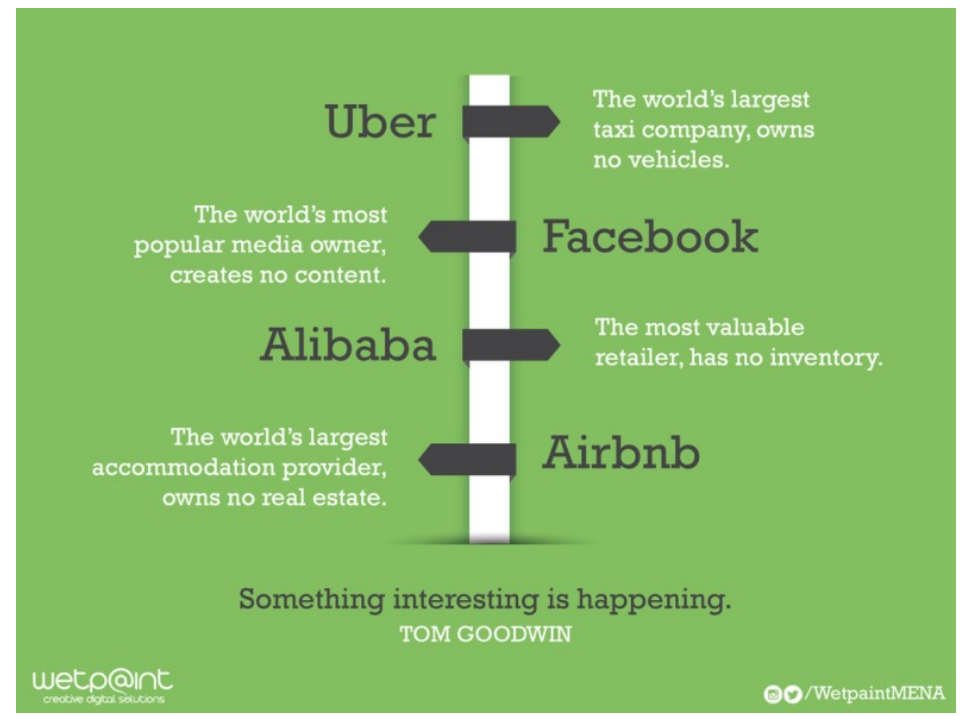

Figure 2 Something interesting is happening

Source: https://twitter.com/itsadam/status/613459095270469633

\section{References}

1. Bencsik, A. (2009): A tudásmenedzsment emberi oldala. Győr, Z-Press Kiadó Kft.

2. Bencsik, A., \&Juhász, T. (2014): Mentori gyakorlat a magyarországi szervezeteknél. Under publishing

3. Bencsik, A., Juhász, T., \& Kovács, Sz. (2014): A tudásmegosztási hajlandóság aktuális kérdései, avagy jobb adni, mint kapni (empirikus vizsgálat alapján). Alkalmazott tudományok Fóruma I. konferenciakötet, 55-61.

4. Bencsik, A., Juhász, T., \& Machova, R. (2014): Mentor system/practice on the behalf of knowledge sharing. Acta Politechnica Hungarica, 2014/Vol.11. No.9, 95-114. 
5. Byrne, E. (1989). Role modelling and mentorship as policy mechanisms: The need for new directions. St Lucia: The University of Queensland.

6. Choo, C. W. (1996): The knowing organization: how organzations use information to construct meaning, create knowledge and make decision. International Journal of Information Management, 16(5), 23-40.

7. Clutterbuck, D. (2002): Mentoring and diversity: an international perspective. Butterworth Heinemann.

8. Davenport, Thomas H: Information Ecology: Mastering the Information and Knowledge Environment; Oxford University Press, 1997

9. Harvey, M., McIntyre, N., Heames, J. T., \& Moeller, M. (2009): Mentoring global female managers in the global marketplace: traditional, reverse and reciprocal mentoring. The International Journal of Human Resource Management, 6, 1344-1361.

10. Levinson, D.J., Darrow, C.N., Klein E.B., Levinson, M.H. \& McKee, B. (1978): The seasons of a man's life. Balantine Books. New York.

11. Nemirovsky, R., \& Solomon, J. (2000): "This is crazy. Difference of differences!" On the flow of ideas in a mathematical conversation. Paper prepared for Videopapers in Mathematics Education Conference. March 9-10, Dedham, MA

\section{Internet pages}

1. https://www.weforum.org

2. https://www.theguardian.com 